\title{
What if schools were lively more-than-human agencements all along? Troubling environmental education with moldschools
}

\author{
Author: Tuure Tammi \\ Affiliation: University of Oulu, Faculty of Education \\ Postal address: Erottajakatu 9a1, 13130 Hämeenlinna, Finland \\ Telephone: +358407015534 \\ email: tuure.tammi@oulu.fi
}

The recent more-than-human turn has increased interest in writing about relations between humans and other animals. In addition, scholars have called for a need to complement the animal turn with a turn to microbes. Microbes entangle all life in relations and participate in processes of living and dying, but thus far, they have been largely absent in environmental education research. This article attempts to think with microbes in environmental education by zooming into the phenomenon of 'moldschools' in Finland. Employing the concept of agencement, the article first explores how school buildings, toxic molds and humans have effectuated each other and introduces the idea of indoor climate crisis. Then the article explores the complexity of everyday life in one moldschool, asking, how was the school becoming felt and practiced differently by children and teachers in relation to material-discursive mold. Finally, the article asks what moldschools might teach us or ask from us in terms of environmental education and ethics. The notion of schools as always already more-than-human agencements is offered to make space for hesitation and curiosity on various scales of connection.

Keywords: School, More-than-human, Multispecies Ethnography, Microbes, Environmental education 


\title{
What if schools were lively more-than-human agencements all along? Troubling environmental education with moldschools
}

\begin{abstract}
The recent more-than-human turn has increased interest in writing about relations between humans and other animals. In addition, scholars have called for a need to complement the animal turn with a turn to microbes. Microbes entangle all life in relations and participate in processes of living and dying, but thus far, they have been largely absent in environmental education research. This article attempts to think with microbes in environmental education by zooming into the phenomenon of 'moldschools' in Finland. Employing the concept of agencement, the article first explores how school buildings, toxic molds and humans have effectuated each other and introduces the idea of indoor climate crisis. Then the article explores the complexity of everyday life in one moldschool, asking, how was the school becoming felt and practiced differently by children and teachers in relation to material-discursive mold. Finally, the article asks what moldschools might teach us or ask from us in terms of environmental education and ethics. The notion of schools as always already more-than-human agencements is offered to make space for hesitation and curiosity on various scales of connection.
\end{abstract}

\section{More-than-human turn and environmental education}

We are living an era when humans' impact on the planet has attained geological magnitude. There is a growing awareness that we are responsible for and are mortally vulnerable to these changes (Gibson, Rose, and Fincher 2015) and that our 'own delusional, self-centred, selfaggrandizing thinking created this predicament' (Nxumalo and Pacini-Ketchabaw 2017, 2). As a response, approaches often referred to as posthumanism and new materialism have increasingly been calling into question the dominant anthropocentric, dichotomic and hierarchical thinking. While socio-constructivist research, for example, has provided the possibility of considering all social phenomena as relationally produced among humans, this 
research stream has simultaneously enacted a separation of culture and nature characteristic of the history of so-called Western thought. Challenging the former division of labor between natural sciences (focusing on things) and social sciences (focusing on meanings), scholars have called for an interdisciplinary approach emphasizing the interdependency and entanglement of matter and meaning, as well as nonhuman and human (Barad 2007; Haraway 2008; Latour 2009; Pickering 2005). These reworkings resonate with much of indigenous metaphysics in which social and material are perceived as co-constituting and 'cohabiting [with] one another, or feeding one another, or making and re-making one another' (Tallbear 2011; see also Watts 2017) even though these connections have not often been acknowledged (Todd 2016). Thus, there has never been a universal 'we': The ongoing effects of current environmental crises are neither equally produced by all human practices, nor do the crises affect all lives similarly (see Nxumalo 2018) ${ }^{1 .}$

These more-than-human approaches take relationality as the primary ontoepistemological unit. For instance, Haraway (2008) insists that becoming is always becomingwith, and Ingold $(2003,301)$ argues for a 'fungal model,' in which ecological relations 'are not really between organisms and their environments, as though each were initially 'independently' of one another, but rather constitute the very existential foundation from which organisms grow' (see also Affifi 2017). Critical voices argue that these theoretizations, nevertheless, flatten the power relations and push patterns of exploitation into the background (Pedersen 2013). However, being entangled in relations does not mean that everything is affecting and being affected in the same way. Thus, the potential in the more-than-human turn is in addressing the differential becomings-with or 'versions' (Despret 2016; Prout 2005) that emerge from the natural-cultural intertwinings. As Prout $(2005,81)$, in the context of childhood studies, has insisted, instead of fixed ideas of what a child or adult is, we should 
ask, 'how do different versions of child and adult emerge from the complex interplay, networking and orchestration of different natural, discursive, collective and hybrid materials?' However, the more-than-human turn insists that we do not limit our analyses to human becomings, but 'cultivate attentiveness' (van Dooren, Kirksey and Münster 2016) towards the ways in which different versions of nonhuman animals, plants or microbes relationally emerge. In this article, I will attempt to put these insights to work in the context of mold problems in Finnish schools (see also Tammi 2019). While doing this, I will craft some ideas on what a microbial turn might mean in environmental education and ethics.

The humanistic and anthropocentric roots - the emphasis on what it means to be human and to participate in human society — and their consequences in Western education are now being increasingly challenged (Humes 2008; Kahn 2008; Pedersen 2010; Snaza et al. 2014; Taylor 2017). With the emphasis on the more-than-human, schools can be thought of as heterogeneous entanglements extending from their infrastructure to plants and nonhuman animals used in food and clothing, onward to various technologies and their local and global networks (Snaza et al. 2014). Analyses have sought to distract the commonly held binaries by drawing attention to the many ways in which people are constituted by and learn with their more-than-human others (Haraway 2008; Pedersen 2010; Snaza et al. 2014; Spannring 2017; Taylor, Blaise, and Giugni 2013; Rautio et al. 2017). More-than-human studies have also challenged anthropocentrism by showing how learning — understood as interpenetration or 'intra-action' (see Barad 2007) of organism and environment —is ubiquitous across the natural world (Affifi 2017; Dalziell 2017). Thus, environmental education scholars have been crafting 'new ways of theorizing and educating about being with, and in relation to, the planet' aiming at a 'healthy, thriving planet that acknowledges the entangled relationship between human and more-than-human world' (Malone and Truong 2017, 5). 
Nevertheless, it has been observed that environment-oriented curricula have had trouble finding their way into schools and when the curricula do, they are at risk of being translated into neoliberal visions of sustainable development (Kahn 2008), practices that objectify animals (Pedersen 2014; Spannring 2017; Tammi et al. 2018) and narrow ideas about the environment (Weston 2004), for example. Investigating how animals are represented in schools, Pedersen (2004) asks who gains and what is hidden in the perceived tendency of schools to prefer small-scale farms over slaughterhouses and pets over laboratory animals. Scholars have contended that critically attuned pedagogies should seek to address and act upon all forms of human and nonhuman oppression and injustice near and far, and striving to achieve this aim requires more intimate dialogue between various critical educational discourses (Bell and Russell 2000; Fawcett 2013; Humes 2008; Pedersen 2010). Thus, there has been a call for a holistic approach to respond to the environmental crisis and the many forms of interconnected environmental, human and animal injustices (Humes 2008; Kalof et al. 2016; Pedersen 2004).

\section{Common worlds at all scales}

Recent studies, especially in the context of early childhood education, have taken a 'common worlds' approach ${ }^{3}$ in order to move beyond any simplistic developmental and anthropocentric views (Taylor 2017; Taylor and Pachini-Ketchabaw 2015, 2016; Nxumalo and PachiniKetchabaw 2017). These studies insist upon 'staying with the trouble' (Haraway 2008, 2016) that our co-implication, encounters and entanglements with other critters in ordinary and everyday life bring into being. What is common to all of these studies is that they challenge the idea of child-animal relations as cute, innocent and unproblematic, thus bringing forth 
how shared vulnerabilities, uncertainties, indeterminacies and potentialities emerge from the complexities and imperfectness of these encounters (see also Hohti \& Tammi 2019).

Still, 'the animal' often implicitly refers to pets or other charismatic animals 'big like us,' while smaller critters, such as insects, have remained 'the unloved others,' unless they are perceived as useful for human endeavors (Lloro-Bidart 2018; Rose and van Dooren 2011). With the more-than-human turn, especially in the context of 'multispecies ethnography,' other than humans previously perceived as 'bare life' or 'that which is killable' are now increasingly considered to appear 'alongside humans in the realm of bios, with legibly biographical and political lives' (Kirksey and Helmreich 2010, 545). These approaches center on 'how a multitude of organisms' livelihoods shape and are shaped by political, economic, and cultural forces' (Kirksey and Helmreich 2010, 545). Thus, the fixed species boundaries are questioned as all living creatures are understood as immersed in and emerging from situated multispecies communities, affecting each others' becoming and knowing (van Dooren, Kirksey and Münster 2016). In order to explore these comminglings, multispecies scholars have developed a range of sensitising concepts, such as 'passionate immersion' and 'attentiveness' (van Dooren, Kirksey and Münster 2016), 'polite visiting' (Despret 2016), 'staying with the trouble' (Haraway 2016), and withling(s) (Tammi et al. 2018). Importantly, these efforts do not merely celebrate the multispecies mingling, but insist asking who benefits when species meet (Haraway 2008; Kirksey and Helmreich 2010).

With an emphasis on the entanglement of humans with their environments at all scales (Haraway 2016), I share the efforts put forward by Hird (2009) and O'Malley (2014) among others, of complementing the animal turn with a turn to microbes. Microbes entangle all life in relations and participate in every process of living and dying (Hird 2009, 128) and cause 
humans to form a rhizome with other animals (Deleuze \& Guattari 1987). We are now increasingly aware that we live our posthuman lives in symbiosis with myriad microbes in our guts (our 'second brain'), on our skin, in our mouth, in the food we eat, in the things we touch, in the air we breathe (Affifi 2017; Yong 2016). But often this world within the one we see with naked eyes in our everyday lives remains imperceptible, unless it is interpreted as intervening human activities. Let me quote Bruno Latour's work at length:

We do not know who are the agents who make up our world. We must begin with this uncertainty if we are to understand how, little by little, the agents defined one another, summoning other agents and attributing to them intentions and strategies. This rule of method is especially important when we are studying a period when the number of agents was suddenly multiplied by millions. [...] When we speak of men, societies, culture, and objects, there are everywhere crowds of other agents that act, pursue aims unknown to us, and use us to prosper [...] Society is not made up just of men, for everywhere microbes intervene and act. (Latour 1993, 35)

I began to include microbes in my thinking about 'the social' and to experiment with the idea of building molds as participants in teaching and learning during my investigations of the phenomenon of school strikes. A few years ago, I read a newspaper article that reported a school strike organized by the parents' association in a small Finnish municipality. The school strike practically meant that parents had collectively decided to homeschool their children for a given period of time (in this case, a week). With the strike, the parents wanted to urge the municipality to take action in renovating their local elementary school that suffered from a mold problem and voiced concern over increasing symptoms, such as runny noses, rashes and respiratory illnesses. Given that compulsory schooling is highly respected in Finland, parents' 
associations have seldom engaged in activism related to schooling. Usually, parents' associations engage in activities such as fundraising and organizing events.

Mold, among other types of indoor air pollution, has been referred to as the fifth indoor air epidemic — the others being asbestos, radon, formaldehyde, and cigarette smoke (Salkinoja-Salonen 2016). During the 2010s, at least 20 school strikes, among other political actions, were organized by parents across Finland. The Audit Committee estimated in 2013 that 172,000-259,200 people in Finland work in schools and kindergartens where significant dampness and mold problems have been diagnosed. Daily exposure to moisture and mold damage has been estimated to concern 62,000-94,000 elementary school pupils and 12,00018,000 high school students (Audit Committee 2013). Overall, the estimated number of people exposed daily is upwards of 600,000 , which totals one tenth of the population. Understandably, the renovation and healthcare costs are significant, not to mention the incalculable emotional and social costs for those who have become severely ill (Audit Committee 2013). Moisture and mold in buildings is not only a national problem as the World Health Organization (WHO) has defined it as a considerable health risk in all countries where people spend a considerable amount of their time indoors (WHO 2009, 1). Research on human activity patterns suggests that people have begun to spend their time differently in part due to the relative privilege and luxury indoors. Humans in particular in the global West have become 'indoor species' (Ott 1989).

For me, the school strikes manifested an interesting blurring of a boundary: environmental health issues could now be found inside buildings designed to 'liberate social processes from the temporal and spatial constraints of "nature" (Ford 2015, 7). In what follows, I first ask, how did moldschools ${ }^{2}$ come into being? Here, I employ the concept of 
'agencement' (Deleuze and Guattari 1987; Despret 2013) which helps me to think and write about schools as historically specific materializations of more-than-human relations. I consider microbes (here, toxic molds) as participants in heterogeneous agencements, through which the microbes and other participants become rendered capable (Despret 2013). Thus, I am not only 'thinking with microbes' (Hird 2009), but also with buildings and bodies (Murphy 2006), when I explore the complex ways in which they may effectuate each other. Here, I draw inspiration partially from Murphy's (2006) analysis of the emergence of sick building syndrome and chemical exposure in office buildings in the U.S. during the 1980s and 1990s as it shares similarities with the current mold issue. Her analysis shows that buildings and bodies are co-produced, and there are as many versions of them as there are knowledge practices that seize them. Following Murphy's $(2006,13)$ definition, assemblages are 'formed of organic and inorganic objects, technologies, bodies, and architecture, and not just of words' none of which can be reduced to others (Pickering 2005). However, agencements are not simply gatherings of objects with predefined powers. These objects are in the state of becoming-with; they effectuate in each other 'the power to be affected'; they 'agence' (Despret 2013, 38). This is why Despret (2013) prefers the original French formulation agencement instead of Massumi's English translation of the term as assemblage. Agencements are open-ended, and when one begins to 'crack open' (Murphy 2006) one agencement, one soon finds it is flowing through many others. One of the benefits in taking a more-than-human turn with the concept of agencement is that it allows me to understand and engage with buildings as ecologies, and to re-situate humans within ecological systems (Gibson, Rose, and Fincher 2015). Humans have not been becoming 'indoor species' (Ott 1989) alone. I will show how the phenomenon of moldschools emerged in the intersections of building and cleaning practices, materials, technologies, microbes, policies and more. 
I then engage with the complexities of this agencement on the mundane level by drawing on my encounters and talks with the teachers, pupils and their parents in one of the moldschools. Initially interested in how the children navigated during this political situation (Tammi 2017), I contacted the chair of the parents' association and made arrangements for a two-week visit. During this visit I talked with and interviewed nine parents (60-90 minutes per interview), twelve children (30-60 minutes per interview) and five teachers (60-90 minutes per interview) of this school of little more than 100 pupils, gathered documents and reports, and breathed the indoor air in the school and people's homes. I ask, how was the school becoming performed and inhabited differently when entangled with 'materialdiscursive' (Barad 2007) mold? How were relations with mold becoming perceptible in everyday life, and what were these accounts making imperceptible? I do this by focusing on the fears, hopes, curiosities, inconveniences, confrontations - the flows of forces inside moldschool agencement - that finding one's way within the moldschool brought about. In the final section, I ask, what could moldschools possibly teach us, or ask from us in these troubled times. I will address some questions regarding microbial knowing and becoming thus attempting to craft ideas on how we might consider environmental education and ethics differently.

\section{Emergence of moldschools and indoor climate crisis}

As Latour (1993), among others, argues, society cannot be made through the social alone. The emergence of moldschools can be mapped through certain inseparable political, economic, technological, cultural and natural developments. One crucial entrance point to the phenomenon of moldschools can be located in the Yom Kippur war and the resultant oil crises in the 1970s: The price of oil quadrupled, and Western governments were forced to search for 
ways to reduce use of fossil fuels. One result was a boom in energy-efficient and superinsulated building and re-building and the corresponding expansion of markets for artificial and chemically processed building materials (Baker 2012; Ionescu et al. 2015; Murphy 2006; Mölsä 2017). However, these changes made buildings more vulnerable to accumulation of moisture and mold growth. For instance, drywall has been found to contain minerals and nutrition (starch, cellulose gum) and the requisite humidity for the toxic species of Aspergillus and Stachybotrys genera, while the plastic covering that protects the gypsum liner keeps the carbon dioxide and humidity levels favorable for mold (Salkioja-Salonen 2016, 24). As houses were becoming air-tight, ventilation could no longer be provided with gravitational means. The move from gravitational to mechanical ventilation systems in buildings was expected to enable better regulation of the indoor climate, as well as provide universal standards for optimal performance, but was later found to sometimes boost circulation of mold spores in buildings (Ford 2015; Murphy 2006; Mölsä 2017). Reviewing SalkinojaSalonen (2016), molds produce vesicles as their metabolic products. The molds exhale humidity. These vesicles contain water-resistant toxins and nutrition for spores to germinate and attach to surfaces. The pressure differences in mechanically ventilated buildings fragment vesicles into airborne nanodrops that can spread across the building and enter the respiratory organs of human inhabitants where the vesicles may cause health effects (Salkioja-Salonen 2016), depending on the immunological status of the bodies (Mousavi et al. 2016). In addition, mechanical ventilation systems have been found to provide dwellings for various molds. For instance, Penicillium expansum has been found in factory-sealed ventilation filters and Chaetominum in supply air filters (Salkinoja-Salonen 2016). Further, to save energy, ventilation systems were often shut down for weekends and holidays, or maintenance was neglected, which further allowed moisture to accumulate (Mölsä 2017). Ventilation machines may also cause underpressure that absorbs particles from the walls into the indoor air (Mölsä 
2017).

In addition to the attempts to condition indoor air, there are attempts to condition microbial life through seeking super-effective ways of killing (all) bacteria. Salkinoja-Salonen (2016) argues that using boron chemicals in materials, such as soundproofing and thermal insulation, and anti-bacterial cleaning products in schools and elsewhere killed most microbes, but at the same time gave a competitive advantage to toxic mold genera resistant to these chemicals. An international comparison of 29 moisture-damaged schools and 27 control schools in Finland, Spain and Holland showed that although the schools in Holland and Spain were significantly more 'dirty' microbiologically, the children in Finnish schools suffered more from symptoms connected to indoor air problems. Thus, the researchers asked whether the schools in Finland have become 'cleaned to death' (Salkinoja-Salonen 2016,105).

In comparison, when studying the microbiome of hospitals, Kembel et al. (2012) found that hospital rooms were colonized by potentially harmful pathogens originating from the mouths and skins of hospital residents, many of which were rare in outdoor air. The microbial diversity was lower indoors than outdoors, and window-ventilated rooms were richer in microbial diversity than those ventilated mechanically. Opening the window allowed benign or harmless microbes from outdoors to occupy the hospital rooms and exclude potential pathogens as the room's microbiota became more diverse. In many schools, ventilation is left to the machines, and opening a window is prohibited (in some schools, windows are even bolted shut) to assure that these machines work properly. In addition to the ways in which rooms are ventilated, the size and type of the room, the rooms' connectedness to each other, the temperature and relative humidity, as well as the frequency of use and movements by humans, influence what is found in room dust (Kembel et al. 2014). 
Practices of effectivity in building, ventilation and killing bacteria were coined with the neglect of maintenance and rebuilding (children's places especially) during the deep economic recession of the 1990s (Mölsä 2017). More recently the precarious capitalist economy has further altered the standards of construction and renovation. Responsibilities are often fragmented and blurred between contractors, subcontractors and sub-subcontractors. Contracts are grounded on low costs, and schedules are made extremely tight due to effectivity pressure (Vesalainen 2018). People may feel that information about the (school) building is being concealed, and their concerns are downplayed, as argued by the parents who organized the school strike. A growing amount of information on human-mold relations is available through the internet, experts, consulting companies, discussion forums and peer groups, shaping the understanding and engagements with molds. Building molds have also become significant business to some. For instance, apartment sales often involve a building inspection, while the inspectors do not take any responsibility for the results.

Although environmental education often materializes as teaching about the environment where interactions with the nonhuman world are mediated through study artifacts within the confines of the built environment, the urgency to enrich traditional disciplines by going out from the school buildings, identifying environmental issues and taking action on them, and enhancing embodied knowledges has been rightly emphasized (Gough 1990; Russell and Bell 1996, see also Fawcett 2013). However, too often the environment is considered to exist outside the school building, and investigating how the indoors might be conceptualized as multispecies sites has been largely absent (however, see Affifi 2017; Weston 2004). While humans have been becoming indoor species, so have a vast number of microbes. After we take microbes seriously, one does not need to leave the school 
building or bring nature into the classroom to be entangled in multispecies becoming. This multispecies becoming is not separable from historically situated practices of building, cleaning and other world-making practices through which matter can come to matter differently for humans and more-than-humans alike. Instead of succeeding in purifying culture from nature, the above-mentioned practices generated new and complex naturalcultural agencements and what could in the case at hand be called an 'indoor climate crisis.'

\section{Teaching and learning with material-discursive mold}

When I entered the field, I became involved with a messy mixture of affects: hesitations, fears, disappointments, empowerments, curiosities and more. The situation felt truly troubling and tense. This tension became manifested in the images of a child the adults brought forward during our talks, for example. Although parents and teachers stated that they had talked with the children about mold when questions arose from the children themselves, the adults nevertheless romanticized childhood (Taylor and Pachini-Ketchabaw 2016) by regarding children as 'living in the moment' and 'being relaxed and worry-free by nature.' There was an emphasis in the teachers' and parents' talk that children should play and study instead of needing to worry about their bodies and indoor air pollution. Adults were 'protecting children's ears,' but the adults also suggested that children actively 'develop all kinds of ideas in their heads' in relation to the ongoing situation. The teachers let me understand that, given the parents' involvement with the issue, it was the parents' duty to decide whether and how to discuss these issues with the children. Some parents stated that their children had often been present when they had talked about mold in their school. Other parents said that schools were in a better position to deal with the issue with the children as the school could inform all the children at once, and the problem was located inside the building. In all, it seemed that there 
was no general educational agreement on how to involve children. The children occupied an awkward and leaky middle place.

Thus, when I asked the teachers how mold as an environmental health issue could be taken up with the pupils, the teachers hesitated. Taking up the prevalent microbial life as a subject of study was perceived as pedagogically ambitious but impossible. This was partly due to its politicization in which these teachers were not eager to take part. They repeatedly expressed that their work was, in part, threatened by the parental activism: Some children had started acting disrespectfully and not completing their homework. The parents, according to them, had suggested to the children that 'something else was more important than school work.' To the teachers, the environmental health issue was a disturbance of the work they were supposed to do: Providing all pupils equally the knowledge and skills needed for their lives as future adults.

According to the teachers, their work was tied to the teaching of the learning goals manifested in the national and school curriculum. They repeated the mantra, 'our job is teaching.' The hesitation was partly due to the absence of microbial substance in the curriculum texts and partly due to developmental views that children are not yet capable of dealing with such issues and that these issues were not perceived as relevant to investigate for elementary school pupils. The teachers also positioned themselves as employees of the municipality, a position that required loyalty to the decisions made by the local government. Daily life in schools, no doubt, is routinized most of the time: Learning is understood as interaction between pupils and teachers and is mediated by books and other study materials, a practice that renders the environment something existing for human knowing. Still, the issue of mold materialized occasionally in questions the pupils asked, clashes between pupils and 
teachers, absences and study arrangements: Classrooms had been closed, some pupils had a doctor's certificate allowing them to be homeschooled in some subjects, one pupil was permanently studying at home and another one pupil was studying in a different building than her classmates, for instance.

Although not all pupils (or teachers) experienced symptoms and illnesses commonly connected to mold problems, such as headaches, tiredness, rashes and respiratory symptoms (Salkinoja-Salonen 2016), the teachers were uncertain about where these effects actually came from. Were the headaches and tiredness merely normal phenomena related to growth or seasonal flu? Did they originate from too little sleep, or were they perhaps psychological caused by the intensification of the mold issue (see also Murphy 2006)? Pupils' differential embodied vulnerabilities had become perceptible in relation to mold and could not be ruled out of teaching and learning. In all, material-discursive mold disturbed the human-centered routines in school, the related dichotomies (e.g., mind and body), and generated new uncertainties.

Still, for the minority, the symptoms were real materializations of the phenomenon of moldschools. When talking with the children, I was told how mold had entangled in their everyday lives, producing new engagements within their environment. For many, the school was not at all the same school it had been earlier. Pupils had hunted and spotted mold from classrooms, hallways and toilets, and been avoiding certain areas in the school, especially those near the classrooms that were closed due to high volumes of toxin-producing molds. Educational materials also became perceived differently: To avoid getting sick, some pupils were secretly avoiding touching certain materials (e.g., fabrics, books and xylitol drops ${ }^{4}$ ) that were brought into their classrooms from moldy parts of the school. Sometimes, the air was 
difficult to breathe. The noise from the air purifier installed in the classroom distracted some of the pupils.

In children, moldschool sometimes invoked speculation about environmental health outside the school as well. Some of them were finding information on the internet and talking and sharing the 'bits and pieces' they had heard, read and observed with their friends. Those who had experienced symptoms and sick leave had begun to pay attention to the way in which their body responded or speculated how their body might respond in different places: in different classrooms, outdoors, at their and their friends' homes. For instance, one child told me about her relative who was smoking inside the car that made her nauseated and wondering whether the raccoon dogs who lived nearby might spread diseases. Perhaps those children who were experiencing symptoms were engaged in similar activity as people with multiple chemical sensitivity in office buildings in that the pupils were 'learning new ways to listen to how your body feels, how it connects to the environment' in order to find themselves a safe place (Murphy 2006, 174). One of the children stated, 'If I start to feel bad in school, if I get a headache [...], I will see if I get any symptoms at home. If they stop, then it [the reason] must be inside the school.'

As a part of our talks, I asked the children to tell a story titled moldschool. While these stories surely included fiction, they effectively brought up potentialities and vulnerabilities related to mold as viewed from the everyday life in schools. The stories included fears of being exposed and falling sick and descriptions of symptoms and their consequences: 'becoming tired and more tired,' 'having a headache and nausea every day,' 'snapping,' 'having to stay home while friends were at school,' having to visit the doctor and being prescribed medicine. In addition, the pupils speculated about people's actions: teachers' 
attempts to solve the issue by re-locating some pupils in different classrooms than their classmates, painting over the mold dots on walls, angry arguments between adults and fights between children regarding the existence and effects of mold, parents' attempts to make others understand the seriousness of the issue, some teachers' reluctance to admit the problem existed, researchers taking samples, newspapers writing about the issue, talking and wondering with peers 'how can it be so that there is mold in school,' children's investigations of the school building at night, deconstructing the school (e.g., by blowing it up), hopes for building a new one where kids could be 'without all the mold stuff' and symptoms, and some partying and hanging out with friends. In all, these stories mixed hopes, fears, frustrations and curiosities, and allowed touching some of the ways in which the agencement was working with them. At the same time, they reminded me that the relation to mold was not the only mattering relation to the children of the moldschool.

We can now consider environmental learning as taking place through unfolding of the environment-body relation and the new embodied knowledges and actions that emerge (see also Affifi 2017). The moldschool created a quest for 'finding a safe space' (Murphy 2006) by inviting the children to re-map the school, listen to embodied messages, talk and demonstrate, among other things. These doings are materialized in a story told by one of the teachers:

The pupils came to school, and they had art lessons held by another teacher. They started to talk about this mold issue between peers. Apparently, things talked about at home grew so huge in the school that they experienced that 'Why aren't these classrooms closed, and why do we have to be here?' They went to the corridor to lie down and complained, 'Now I have a headache, I feel sick.' Then I came and talked with them, and I suggested that the 'school nurse will come in the afternoon and listen 
to what health issues you have. I don't understand so much about them myself.' And we made a deal. They calmed down and came into the classroom, and we studied the day in the normal manner, and the school nurse came in the afternoon. We have a great school nurse who listens to the children a lot, but in this situation, we didn't clearly plan what she should say, and she said approximately the same calming expressions as I did and had no intention of listening to individual children's symptoms. The children experienced this as downplaying, and four pupils skipped the rest of the classes as a kind of a protest. There were only a few pupils left, and we said that you cannot leave the school in the middle of the day, that it's in no way [appropriate]. And these who stayed at school wondered how they could do it. Then we, of course, contacted the homes that this is not acceptable that pupils leave during the school day as the supervision of the route between school and home is not arranged. The pupil is basically on the school's responsibility. Somehow, a kind of a workplace accident had happened. I had promised them something the school nurse didn't fulfill.

Along with the emergence of the mold issue, the school was becoming practiced differently. Material-discursive mold gave rise to new questions and tensions in the everyday school life. The building, its inhabitants and air were no longer self-evident. Still, they were attempted to be distanced from the official schooling. Perhaps in the practicing of the official school-the one that agences teachers to attempt to stick with the lesson plans, routinized practices and familiar interactions - teachers find it next to impossible to allow teaching to 'go wild' (Weston 2004) and to venture into the space of unanticipated intra-actions. The desire to control is present in the design of school buildings, rules, positioning of teachers and pupils, regulations and images of the child, among other things. Mold agencement does not easily fit into this framework as it generates uncertainty. There are no pregiven instructions for dealing 
with situated phenomena, such as moldschools, as they emerge in the intersections of the particular and the universal, through de-familiarization of the familiar, the in-betweens of humans and more-than-humans. Still, they are right here.

I find it intriguing how the phenomena that are on its skin (and in this case, permeating it and partly constituting it) seem to trouble the official school. Perhaps this is a diffraction of the anthropocentric desire to study the world from a distance: education about environment (Russell and Bell 1996). When there is no distance to begin with and safety is becoming an everyday quest (when our more-than-human becoming is within our bodies, in the air we breathe, in our dwellings), centering on human alone is simply not enough.

While moldschool agencement was effectuating children and school staff and becoming perceptible for them in several ways, there were also important imperceptibilities. First, in everyday life in the moldschools, building molds may appear to have 'nothing good in them' and be 'disgusting,' as expressed by two of the children. Likewise, in the general discourse, molds appear as a unified pathogenic group and an enemy. However, the same molds (e.g., Aspergillus fumigatus) that can cause health problems in humans and other animals are also crucial decomposers on which the well-being of the planet partly depends (Mousavi et al. 2016) or are used extensively in the food industry. For instance, Aspergillus niger is used to produce citric acid (E330; Salkinoja-Salonen 2016). Capabilities emerge from the relational spacetime. Maybe in buildings, these critters are trying to make an 'earthy living' (Haraway 2008), 'searching' for a livable space, responding within their environments (Affifi 2017). Although health symptoms in humans can distract their living significantly, drifting in the human body, where most building molds cannot live or reproduce (Salkinoja-Salonen 2016), is an undesirable situation for the toxic mold as well. On the other hand, landing on 
clothing or books may help spores to spread into new environments.

Second, what seems to remain largely imperceptible (especially for pupils) are the manifold processes through which moldschools came into existence and to which they connect and whom they benefit. As argued in the previous section, the attempts to separate and kill may have partly driven buildings into this situation. One child, when talking about the moldy study materials, referred to the cleaning practices: 'They said they should have been ozonized. They were merely disinfected a bit from the top, and it does not help.' Although at first it seems that building molds are not easily harnessed into the service of humans and the capitalist economy, they (among other indoor air problems), nevertheless, have contributed to an increase in building projects and industry (e.g., mold-resistant materials are now available), businesses conducting building inspections, scientific indoor air tests (where rabbit skin, mice brain cells and boar sperm are used as indicators of toxicity - another example of uneven multispecies communities) and inquiries into experienced symptoms, development of diagnoses (e.g.. sensitivity-related illnesses) and related medical treatment, among other things. Although there are some arguments that microbes should be included in compulsory education (Barberán et al. 2016), I am doubtful whether this would help understanding and acting upon the complexities involved in more-than-human agencements. For instance, climate change education research has shown us that increased scientific literacy and numeracy may not be sufficient to increase concern regarding climate change (Kahan et al. 2012). The multifaceted environmental problems we face demand an interdisciplinary approach (Pickering 2005) and consideration of them as agencements (Despret 2013).

I am intrigued to ask, could taking up the phenomenon of moldschools as a study project with pupils work toward a better understanding of the mutual becoming and 
interdependence of humans and other critters, as well as societal and capitalist processes that generate differential vulnerabilities? As I have pointed out, the teachers may consider taking up these complexities in a classroom too difficult, risky or otherwise not belonging to their work. Yet it appears to me that the children were already engaged in environmental learning through their embodied knowledges, re-mappings and actions they took in their everyday lives. Living with mold agenced ethical questions regarding how to do well. Materialdiscursive mold was, in one sense, teaching them. Further, if we move beyond the teacherpupil relation, it becomes possible to ask how environmental education and learning were taking place in the moldschool all along: through building practices and ventilation, use of chemicals in cleaning, takeover by toxic molds, health effects and absences of pupils and teachers, demonstrations, the re-mappings of the school building, as well as the more playful activities (e.g., mold hunting) the agencement inspired, incited, evoked.

\section{Attuning to microbial life in environmental education and ethics}

It is difficult in the current situation not to be involved with building molds. Every day, when I take my son to his daycare, we pass by three empty educational institutions that were closed within the past few years due to mold problems. One day, the city provided my photographer friend the keys to one of these school buildings, and he asked me to accompany him. We walked in from the main doors and found desks and chairs piled on top of each other, waiting for a ride to the junkyard. One floor up, abandoned books and papers were a mess on the hallways and classrooms, cupboards were left open, some full of educational materials. One classroom had a table full of stuffed animals, another was equipped with microscopes and chemistry equipment and in yet another, there were computers. We went down to the basement and found an archive of educational technologies ranging from cinefilms and boards 
representing historical events to slide projectors and reel-to-reel machines to abacuses and statues. These were no longer merely instructional devices but devices allied with molds. The air indoors felt heavy, but mold was nowhere to be seen. We hunted for mold with our eyes and noses. Nothing. But when we closed the school's door behind us, we felt the difference between the stuffy air indoors and the cold, fresh air outdoors. Our bodies became differently related, largely beyond our awareness.

Moldschools work as a powerful reminder of situatedness, relationality and continuous and often conflicting engagement in world-making encounters of diverse associates. As my findings regarding the complexities in the everyday lives in a moldschool suggest, through these encounters the school is no longer what it was thought to be, and its human inhabitants are not quite what was anticipated either. In other words, material-discursive mold troubles anthropocentric epistemologies and ontologies: the commonly held dichotomies (e.g., nature/culture, body/mind), school routines, relations with materials and more. In many cases, teachers have had to quit their work, sometimes leading to a string of supply teachers, negatively affecting learning processes. Mold related illnesses are distracting pupils' participation in teaching and learning and sometimes isolating them from their peers. Still, it seems that the official school tends to distance itself from the conflicting multispecies entanglements taking place right here. Unloved microbial companions cannot, however, be wished away. As Lloro-Bidart (2018) concludes in her study on human-invertebrate relations, there is a contradiction in urging pupils to care for the environment while at the same time pushing some critters outside caring practices as "not only are these nonhuman others also part of our shared ecologies and socioecological histories and should be understood as such, but how we act toward them [...] can have drastic consequences for all living entities.' 
Perhaps the pedagogical hesitation is related to the tendency of viewing toxic molds and other indoor air issues as problems themselves and not materializations of the grander problematic of anthropocentric (and economy driven) practices. In talking about global heating, Hird $(2009,129)$ points out that 'humans might ultimately render the biosphere inhospitable for humans and other animals, but this shifted biosphere will certainly survive our extinction.' Indoor climate crisis in not too different from this. Although certain processes have rendered the buildings uninhabitable for some humans (we now talk about 'mold refugees') and microbial critters, they have not done so to some toxic molds. Apparently, this has happened largely due to the quest for energy- and cost-efficiency coined with the lack of attentiveness in bodies, microbial life and emerging capabilities.

Moldschools call for attuning to the differential becomings and vulnerabilities not only in humans but also in buildings and microbiota, among others. For instance, pupils are becoming differently vulnerable within their schools, and schools may differ in their microbiota, producing differential vulnerabilities in societal and global scales. Further, the microbial communities are becoming differently affected in schools, in relation to the practices of building, killing, ventilation and other actions affecting microbial diversity. These nested practices of ignorance have fed back to humans as illnesses, but at the same time, could these illnesses be regarded as new sensibilities, new response-abilities? If we accept this provocative suggestion, we may ask, what are these symptoms making available for us, what are they asking from us, what are they making urgent?

Re-thinking the environment as not the surroundings of given critters but instead as the emergent phenomenon of their commingling (Haraway 2008; Ingold 2003; Tallbear 2011) allows us to entertain an idea of environmental education as being not only about the 
environment (Edwards and Cutter-Mackenzie 2011; Russell and Bell 1996) but also thinking of it as being of the environment. The environment may be characterized as being always already educational in the way it affects and is affected by given human and nonhuman becomings and processes constituting it (Affifi 2017). Thus, multispecies scholars have called for cultivating 'arts of attentiveness' by asking what matters to those we live with, including the awkward, unloved and loathed animals, plants, fungi and microbes (Despret 2016; van Dooren, Kirksey and Münster 2016).

While studies on toxic molds' sociability are very limited, I would like to speculate and get wild with the recent studies on slime mold (Physarum polycephalum). This critter has been found to be able to interpret environmental cues, memorize, practice forethought, and respond to the unpredictabilities of its circumstances (Dalziell 2017). As Physarum does not have any centre (e.g., brain) in which to locate its 'cognitive' capabilities, Dalziell (2017) suggests that it challenges the idea that consciousness is produced by the body. Instead, consciousness could be regarded as 'written into the repertoire of materiality, its biological possibilities, such that matter is the capacity to think, to cognise' (Dalziell 2017, 170). Interestingly, depending on the environmental conditions, slime mold sometimes appears as singular (single celled spores) and sometimes as plural (plasmodium), provoking hesitation on how to address it/them and reminding Deleuze \& Guattari’s (1987) notion that monism=pluralism. While there seems to be a tendency to think of Physarum's capabilities as inherent and not arising from the particular material practices (see also Barad 2007), these studies allow important speculations for environmental education. What if we entered places as if they were always already knowledgeable? What if we considered buildings and classrooms as always already alive, already mattering, beyond humans? What if we acted 'as if everything matters' (Carruthers 2006)? Could such questions sensitise us to better recognize 
practices of both suppression and flourishing in human and more-than-human worldings?

Although moldschools are in many ways sad occasions of multispecies becoming, these schools may also work as reminders that even when there is no detected indoor air problem, microbes are there. In reference to the recent more-than-human turn in environmental education, I thus suggest that the (school's) interior is always already a lively multispecies community in-the-making. Attuning to microbial life in buildings and elsewhere could bring to our attention the interrelated materialities, such as walls, machines, cleaning liquids, weather, air, dirt and dust, and their potential significance in environmental education and ethics. By asking, how do microbes come to know, be and do in the world, the attention is drawn to the myriad ways in which world can come to matter, to the ways in which the world can come to know itself or make itself intelligible (Barad 2007). Cultivating attentiveness to all modes of knowing, becoming and doing, both human and more-than-human, is to give worth to different co-existing versions of mattering. This is one of the most crucial, yet troubling exercises for cultivating critical and caring thought (Haraway 2016, 116). The ethical questions of how to care (e.g., how to meet, eat, breathe and kill well) are continuously present in the ordinary and everyday life in schools even when there is no detected indoor air problem. The quest for caring needs to be extended from recycling and other practices of consumption to the attentiveness towards the onto-epistemologies in our surroundings, and within our bodies, for humans are environments too. Of course, we have no certainty of how bodies may affect and become affected. But maybe this uncertainty is what allows us to question 'our responses and accountabilities' and remain hesitant and 'curious about the ethical implications of certain acts of caring rather than taking them for granted' (Nxumalo and Pachini-Ketchabaw 2017, 3). I hope that my efforts in conceptualizing educational practices and places as always already more-than-human agencements as well as the 
sensitising questions I have posed regarding the difficulties in attuning to microbial life further inspires such hesitation and curiosity.

\section{Acknowledgements}

I thank my colleagues at the Animate project, for the ongoing feedback, discussions and experimentations in the more-than-human world. I also thank the article's anonymous reviewers and the editors of this Special Issue for their comments and suggestions that were invaluable for the development of this article.

\section{Funding}

This research was supported by grants from Ella and Georg Ehrnrooth foundation, Emil Aaltonen foundation and Eudaimonia Institute at the University of Oulu.

\section{References}

Affifi, Ramsey. 2017. "The metabolic core of environmental education." Studies in Philosophy and Education, 36, no.3: 315-332.

Audit Committee. 2013. Rakennusten kosteus- ja homeongelmat. [The moisture and mold problems in buildings]. Finnish parliament: Audit Committee report 1/2013.

Baker, Lindsay. 2012. A History of School Design and Its Indoor Environmental Standards, 1900 to Today. Washington: National Clearinghouse for Educational Facilities.

Barad, Karen. 2007. Meeting the Universe Halfway: Quantum Physics and the Entanglement of Matter and Meaning. Durham \& London: Duke University Press. 
Barberán, Albert, Tobin Hammer, Anne Madden, and Noah Fierer. 2016. "Microbes Should Be Central to Ecological Education and Outreach.” Journal of Microbiology \& Biology Education, 17, no. 1: 23-28. http://doi.org/10.1128/jmbe.v17i1.984.

Bell, Anne, and Constance Russell. 2000. "Beyond human, beyond words: Anthropocentrism, critical pedagogy, and the poststructuralist turn." Canadian Journal of Education, 25, no.3: $188-203$.

Carruthers, Beth. 2006. Praxis: Acting as If Everything Matters. MA thesis, Lancaster University.

Dalziell, Jacqueline. 2017. Microbiology as sociology: The strange sociality of slime. In What if culture was nature all along?, edited by Vicky Kirby, 153-178. Edinburgh: Edinburgh University Press.

Deleuze, Gilles, and Felix Guattari. 1987. A thousand plateaus. Minneapolis: University of Minnesota.

Despret, Vinciane. 2013. "From secret agents to interagency." History and Theory, 52, no. 4: 29-44.

Despret, Vinciane. 2016. What would animals say if we asked the right questions? Minneapolis: University of Minnesota Press.

Van Dooren, Thom, Kirksey, Eben and Ursula Münster. 2016. ”Multispecies Studies. 
Cultivating Arts of Attentiveness." Environmental Humanities, 8, no. 1: 1-23.

Donziger, Steven. 2016. "Chevron's “Amazon Chernobyl” in Ecuador: The Real Irrefutable Truths About the Company’s Toxic Dumping and Fraud.” Huffington post, May 27, 2016. https://www.huffingtonpost.com/steven-donziger/chevrons-amazonchernobyl_b_7435926.html?guccounter=1.

Edwards, Susan, and Amy Cutter-Mackenzie. 2011. ’Environmentalising early childhood education curriculum through pedagogies of play." Australasian Journal of Early Childhood, 36, no.1: 51-59.

Fawcett, Leesa. 2013. "Three degrees of separation: Accounting for naturecultures in environmental education research." In The international handbook for research on environmental education, edited by Robert Stevenson, Michael Brody, Justin Dillon and Arjen Wals, 409-417. New York: Routledge.

Ford, Derek. 2015. "The pneumatic common: Learning in, with and from the air." Educational Philosophy and Theory, 47, no. 13-14: 1405-1418.

FNBE. 2014. Perusopetuksen opetussuunnitelman perusteet [The National Core Curriculum for Basic Education]. Helsinki: Opetushallitus.

Gibson, Katherine, Deborah Bird Rose, and Ruth Fincher. 2015. Manifesto for Living in the Anthropocene. Brooklyn: Punctum. 
Gough, Noel. 1990. "Renewing our mythic links with nature: Some arts of becoming ecopolitical in curriculum work." Curriculum Perspectives, 10, no.2: 66-69.

Haraway, Donna. 2008. When Species Meet. Minneapolis: University of Minnesota Press.

Haraway, Donna. 2016. Staying with the trouble. Durham \& London: Duke University Press.

Hird, Myra. 2009. The origins of sociable life: Evolution after science studies. London: Palgrave Macmillan.

Hohti, Riikka, and Tuure Tammi. 2019. The greenhouse effect: Multispecies childhood and non-innocent relations of care. Childhood.

Humes, Brandy. 2008. ”Moving toward a liberatory pedagogy for all species: Mapping the need for dialogue between humane and anti-oppressive education." Green Theory \& Praxis: The Journal of Ecopedagogy, 4, no.1: 65-85.

Ingold, Tim. 2003. ”Two Reflections on Ecological Knowledge.” In Nature Knowledge: Ethnoscience, Cognition, and Utility, edited by Glauco Sanga and Gherardo Ortalli, 301-311. Oxford: Berghahn Books.

Ionescu, Constantin, Tudor Baracu, Gabriela-Elena Vlad, Horia Necula, and Adrian Badea. 2015. "The historical evolution of the energy efficient buildings." Renewable and Sustainable Energy Reviews, 49: 243-253.

Kahan, Dan, Ellen Peters, Maggie Wittlin, Paul Slovic, Lisa Ouellette, Donald Braman \& 
Gregory Mandel. 2012. The polarizing impact of science literacy and numeracy on perceived climate change risks. Nature climate change, 2, no.10: 732-735.

Kahn, Richard. 2008. ”Towards ecopedagogy: Weaving a broad-based pedagogy of liberation for animals, nature, and the oppressed people of the earth." In The critical pedagogy reader, edited by Antonia Darder, Martha Baltodano and Rodolfo Torres, 522-540. New York: Routledge.

Kalof, Linda, Joe Zammit-Lucia, Jessica Bell, and Gina Granter. 2016. ’Fostering kinship with animals: animal portraiture in humane education." Environmental Education Research, 22, no.2: 203-228.

Kembel, Steven, Evan Jones, Jeff Kline, Dale Northcutt, Jason Stenson, Ann Womack, Brendan Bohannan, G. Brown, and Jessica Green. 2012. ”Architectural design influences the diversity and structure of the built environment microbiome.” The ISME journal, 6, no.8: 1469-1479.

Kembel, Steven, James Meadow, Timothy O’Connor, Gwynne Mhuireach, Dale Northcutt, Jeff Kline, Maxwell Moriyama, G. Brown, Brendan Bohannan, and Jessica Green. 2014. "Architectural design drives the biogeography of indoor bacterial communities." PloS one, 9 , no.1. https://doi.org/10.1371/journal.pone.0087093

Kirksey, Eben, and Stefan Helmreich. 2010. "The Emergence of Multispecies Ethnography." Cultural Anthropology, 25, no.5: 545-576. 
Latour, Bruno. 1993. The pasteurization of France. Cambridge, MS, London: Harvard University Press.

Latour, Bruno. 2009. “A Collective of Humans and Non Humans: Following Daedalus’s labyrinth." In Readings in the Philosophy of Technology, edited by David Kaplan, 156-172. Plymouth: Rowman \& Littlefield.

Lloro-Bidart, Teresa. 2018. "Cultivating affects: A feminist posthumanist analysis of invertebrate and human performativity in an urban community garden.” Emotion, Space, and Society, 27: 23-30.

Malone, Karen, and Son Truong. 2017. "Sustainability, education, and anthropocentric precarity." In Reimagining Sustainability in Precarious Times, edited by Karen Malone, Son Truong and Tonia Gray, 3-16. Singapore: Springer.

Mousavi B, M. Hedayati, N. Hedayati, M. Ilkit, and S. Syedmousavi. 2016. "Aspergillus species in indoor environments and their possible occupational and public health hazards." Curr Med Mycol., 2, no.1: 36-42.

Murphy, Michelle. 2006. Sick building syndrome and the problem of uncertainty:

Environmental politics, technoscience, and women workers. Duke University Press.

Mölsä, Seppo. 2017. Näin Suomi homehtui - hyvä rakentamistapa sai aikaan pahaa jälkeä. [This is how Finland molded - the good practice of building gone awry.] 
https://www.rakennuslehti.fi/2016/06/nain-suomi-homehtui-hyva-rakentamistapa-sai-aikaanpahaa-jalkea/.

Nxumalo, Fikile. 2018. "Situating Indigenous and Black Childhoods in the Anthropocene." In Research Handbook on Childhoodnature, edited by Amy Cutter-Mackenzie, Karen Malone, and Elisabeth Barratt Hacking. Cham: Springer International Handbooks of Education.

Nxumalo, Fikile, and Veronica Pacini-Ketchabaw. 2017. "'Staying with the trouble' in childinsect-educator common worlds." Environmental Education Research, 23, no.10: 1414-1426.

O'Malley, Maureen. 2014. Philosophy of Microbiology. Cambridge: Cambridge University Press.

Ott, Wayne. 1989. Human activity patterns: a review of the literature for estimating time spent indoors, outdoors, and in transit. US Environmental Protection Agency.

Pedersen, Helena. 2004. "Schools, speciesism, and hidden curricula: The role of critical pedagogy for human education futures.” Journal of Futures Studies, 8, no.4: 1-14.

Pedersen, Helena. 2010. ”Is 'the posthuman' educable? On the convergence of educational philosophy, animal studies, and posthumanist theory." Discourse: Studies in the Cultural Politics of Education, 31, no.2: 237-250.

Pedersen, Helena. 2013. "Follow the Judas Sheep: materializing Post-Qualitative methodology in Zooethnographic Space." International Journal of Qualitative Studies in 
Education, 26, no.6: 717-731.

Pickering, Andrew. 2005. "Asian eels and global warming: a posthumanist perspective on society and the environment." Ethics \& The Environment, 10, no.2: 29-43.

Prout, Alan. 2005. The Future of Childhood: Towards the Interdisciplinary Study of Children. London: Routledge Falmer.

Rautio, Pauliina, Riikka Hohti, Riitta-Marja Leinonen and Tuure Tammi. 2017.

"Reconfiguring urban environmental education with 'shitgull' and a 'shop'." Environmental Education Research, 23, no.10: 1379-1390.

Rose, Deborah Bird and Thom van Dooren. 2011. "Unloved Others: Death and Disregard in the Time of Extinctions." Australian Humanities Review, 50: 1-178.

Russell, Constance, and Anne Bell. 1996. ”A politicized ethic of care: Environmental education from an ecofeminist perspective.” In Women's voices in experiential education, edited by Karen Warren, 172-181. Dubuque, IA: Kendall Hunt.

Salkinoja-Salonen, Mirja. 2016. Diagnostisia työkaluja rakennusten patologiaan. [Diagnostic tools for the pathology of buildings.] Helsingin yliopisto: Mikrobiologian julkaisuja 50.

Snaza, Nathan, Peter Appelbaum, Siân Bayne, Dennis Carlson, Marla Morris, Nikki Rotas, Jennifer Sandlin, Jason Wallin, and John Weaver. 2014. “Toward a Posthumanist Education.” Journal of Curriculum Theorizing, 30, no.2: 39-55. 
Spannring, Reingard. 2017. "Animals in environmental education research." Environmental Education Research, 23, no.1: 63-74.

Tallbear, Kim. 2011."Why Interspecies Thinking Needs Indigenous Standpoints." Theorizing the Contemporary, Cultural Anthropology, April 24, 2011. https://culanth.org/fieldsights/260why-interspecies-thinking-needs-indigenous-standpoints

Tammi, Tuure. 2017. Poliittinen prosessi ja demokratiakokeilujen tartunnat koulun arjessa. (The political process and the contagions of democratic experiments in everyday life in school). Doctoral dissertation. University of Helsinki: Studies in Education.

Tammi, Tuure. 2019. Breathing well at the wastelands? Indoor climate change in schools and the daily lives of arctic children. In Social, Material and Political Constructs of Arctic Childhoods - An Everyday Life Perspective, edited by Pauliina Rautio and Elina Stenvall. Springer.

Tammi, Tuure, Pauliina Rautio, Riitta-Marja Leinonen, and Riikka Hohti. 2018. Unearthing withling(s): Children, tweezers and worms, and the emergence of joy and suffering in a kindergarten yard. In ChildhoodNature Child-Animal Relations, edited by Tracy Young and Pauliina Rautio. Springer Nature.

Taylor, Affrica. 2017. Romancing or Re-configuring Nature in the Anthropocene? Towards Common Worlding Pedagogies. In Reimagining Sustainability in Precarious Times, edited by Karen Malone, Son Truong and Tonia Gray, 61-76. Singapore: Springer. 
Taylor, Affrica, Mindy Blaise, and Miriam Giugni. 2013. ’Haraway's ‘bag lady story-telling’: Relocating childhood and learning within a 'post-human landscape'." Discourse: Studies in the Cultural Politics of Education, 34, no.1: 48-62.

Taylor, Affrica, and Veronica Pacini-Ketchabaw. 2015. ’Learning with children, ants, and worms in the Anthropocene: Towards a common world pedagogy of multispecies vulnerability." Pedagogy, Culture and Society, 23, no.4: 507-529.

Taylor, Affrica, and Veronica Pacini-Ketchabaw. 2016. "Kids, raccoons, and roos: Awkward encounters and mixed affects." Children's Geographies, 15, no.2: 131-145.

Todd, Zoe. 2016. "An Indigenous feminist's take on the ontological turn: 'ontology'is just another word for colonialism.” Journal of Historical Sociology, 29, no.1: 4-22.

Vesalainen, Suvi. 2018. "Tuore raportti sisäilmaongelmista paljastaa: Pääsyyt ongelmiin ovat riskinotto, välinpitämättömyys ja raha.” [Recent report on indoor air problems: main reasons are risk taking, neglectance and money]. Yle, March 19, 2018. https://yle.fi/uutiset/310116480.

Watts, Vanessa. 2017. ’Indigenous place-thought \& agency amongst humans and non-humans (First Woman and Sky Woman go on a European world tour!).” Re-visiones, 7. http://revisiones.net/index.php/RE-VISIONES/article/view/228/409

Weston, Anthony. 2004. "What if teaching went wild?" Canadian Journal of Environmental Education, 9: 31-46. 
WHO. 2009. WHO guidelines for indoor air quality: dampness and mould. World Health

Organization. http://www.euro.who.int/data/assets/pdf_file/0017/43325/E92645.pdf

Yong, Ed. 2016. I contain multitudes: The microbes within us and a grander view of life. New

York: Harper Collins.

1 I cannot help thinking about the recent news about the toxic dumping by the oil company Chevron in the Amazon in Ecuador that has had drastic effects on the indigenous people and more-than-humans, for example (see Donziger 2016).

3 The common worlds approach “"merges Latour's (2009) notion of common worlds as a collective of human and non-human constituents with Haraway's (2008) grounded and relational 'worldly' ethics" (Taylor and Pachini-Ketchabaw 2016).

2 'Moldschool' is a vernacular term used to refer to schools (and other educational institutions) where an indoor air problem often caused by toxic molds has been detected or assumed. Whereas 'sick building' in the 1980s signaled confusion between buildings and the bodies in them (Murphy 2006), moldschools signal confusion between nature (mold) and culture (school), already teasing out images of the school as a multispecies site.

4 I count xylitol-drops as materials for (dental) health education as pupils are obliged to take them after each meal in order to prevent acid attack. 